\title{
Effects of Manual Therapy on Pain and Function of Patients with Chronic Low Back Pain
}

\author{
Kyoung Kim¹, Kwan-sub Lee², Seok-Joo Choi ${ }^{3}$, Chun-Bae Jeon ${ }^{4}$, Gook-Joo Kim¹ \\ 'Department of Physical Therapy, College of Rehabilitation Science, Daegu University, Daegu; '²Department of Physical Therapy, Kang Hospital; \\ ${ }^{3}$ Department of Physical Therapy, Daegu Science University, Daegu; ${ }^{4}$ Department of Physical Therapy, The Most Holy Trinity Hospital, Daegu, Korea
}

Purpose: This study was conducted to determine how a manual therapy (joint mobilization and flexion-distraction technique) would affect pain and function with the chronic low back pain.

Methods: Thirty patients were assigned to either the experimental group $(n=15)$ or the control group $(n=15)$. Patients in the experimental group performed joint mobilization and flexion-distraction technique. Patients in the control group performed spinal decompression therapy. Both exercises were performed for three days per week, for a period of six weeks. Pain was measured by the visual analogue scale (VAS) and functional disability was measured using the Oswestry disability index (ODI). A paired t-test was used for identify differences before and after treatment, and an independent t-test was used to identify differences between treatment groups.

Results: In the within group comparison, the experimental group and control group differed significantly for all variables $(p<0.05)$. However, no significant differences were observed in any variables between groups $(p>0.05)$.

Conclusion: The above results confirmed that it is necessary to confirm the various benefits of therapy with the joint mobilization and the flexion-distraction technique. The findings of the concerned study will be useful to doctors applying therapy to treat patients with the chronic low back pain.

Keywords: Manual therapy, Chronic low back pain, VAS, ODI

서 론

여러 근골격계 질환 중 요통은 일상에서 흔히 발생하는 질환이고 일 상생활의 지장과 함께 치료를 위한 비용의 증가로 이어져 삶의 질에 큰 영향을 미치는 요인 중 하나이다. ${ }^{1}$ 요통을 일으키는 원인은 척추 자체 병변으로 생기는 구조적 원인과 스트레스에 의한 심리적 요인, 복강 내 장기나 생식기 질환, 그리고 근 골격계의 기능 저하 때문에 생 기는 생체역학적 요인 등이 있으며, 그 중에서도 대부분이 체간의 연 부조직 손상이나 근력 약화에 따른 요부의 불안정성 같은 역학적 원 인에 의한 것이다. 이러한 원인으로 발생한 통증은 활동의 제한과 관 절 사용의 감소, 이차적 근력약화를 초래하며 신체기능과 생산 활동 을 저하시키는 악순환으로 이어진다..$^{2-5}$ 만성요통이란 요통의 원인이 사라졌음에도 불구하고, 통증이 3-6개월 이상 지속되면 만성요통으 로 분류한다. ${ }^{6}$ 만성 요통은 치료의 예후도 나쁘고 통증의 지속성으 로 인하여 환자 개인의 사회적, 심리적 안정에도 지대한 영향을 끼치
고 있다. 요통 환자들은 일반적으로 보존적인 치료와 운동치료를 강 조하고, 이러한 치료에 효과가 없거나 상태가 심각한 경우 수술을 시 행하게 되지만 무엇보다 요통을 치료하는데 중요한 부분은 신체적인 문제와사회 심리적인 문제를 포함한 포괄적인 치료방법을 선택하는 것이다. ${ }^{8-10}$

$\mathrm{Bae}$ 등 ${ }^{11}$ 은 통증, 제한된 움직임 그리고 나쁜 자세로 인한 문제를 치 료하는데 있어 도수치료가 이용된다고 하였으며, 도수치료기법의 핵 심원리는 기능부전의 척추와 사지의 근육, 관절을 다양한 도수 교정 치료기법을 이용해 근육의 신장, 관절가동범위와 변위의 정상화, 유 착을 제거 등으로 근골격계적 증상과 신경을 회복시킨다. 도수치료 기법의 범주에는 근골격계의 관절이나 연부조직의 가동술, 도수교 정, 정골요법, 결합조직 마사지, 근막이완술, 굴곡 신연기법, 근에너지 기법 등이 포함될 수 있다. ${ }^{2}$ 척추 도수치료 중에서 관절가동기법은 동통이나 근방호 또는 근경련 등에 신경생리학적 그리고 기계적인 측면에 영향을 주며, 가역성(reversible)이 있는 저가동성(hypomobili- 
ty)관절이나 점진적으로 가동성에 제한이 나타나고 있는 관절 그리 고 기능적으로 고정된 관절의 치료에 효과적이다. ${ }^{13}$ 또한 기능부전이 있는 척추의 가동범위를 증가시키고 통증을 경감시키기 위하여 척 주에 많이 사용되고 있으며, 관절의 자유로운 동작을 허용하기 위해 신연(distraction), 활주(gliding), 압박(compression), 구르기(rolling), 회 전(spinning) 등의 방법을 적절하게 적용하여 뻣뻣한 조직을 스트레 칭 시켜 관절가동범위를 증가시킬 수 있다. ${ }^{14}$ 도수치료 방법 중 굴곡신연기법 치료는 척추주위 인대의 협착감소, 디스크내의 대사물질의 이동 증가, 척추 후관절 개방을 통한 후방디스크에 가해지는 스트레 스 및 내압 감소, 그리고 추간공 확장 등을 통해 손상된 척추신경과 주위구조물을 회복시킬 목적으로 사용하는 치료 기술이다..$^{5}$ 또한 척추 후관절의 변위를 복귀시켜 후방척추운동의 정상범위 유지, 운 동기능 향상과 자세교정을 통한 통증 감소로 신체기능을 향상시킬 뿐만 아니라, 단순한 염좌와 타박상에서부터 심각한 추간판 탈출증 으로 인한 다양한 요통에 적용된다고 보고하였다. ${ }^{16}$

요통 환자의 보존적 치료로 최근에는 견인치료의 단점을 보완한 척추감압치료(spinal decompression therapy)가 적용되고 있다. 척추감 압치료는 미항공우주국(NASA) 우주인들이 실험 중 우주여행의 무 중력상태에서 추간판 높이가 증가되어 요통이 해소되고 키가 커지는 현상에 착안하여 개발된 치료 방식으로, 탈출되어 있는 추간판에 음 압을 가해 튀어나와 있는 추간판이 제자리로 돌아가게 만드는 치료 원리로 수핵의 돌출과 근경직을 줄여 주고 척추의 안정과 길이 신장 에도 효과적이다. ${ }^{7}$ 척추감압치료는 일반적인 견인의 사용이 어려운 부분에 대한 3 차원적인 견인, 심리적 안정감, 인대 및 근육에 무리를 주지 않는 범위 내에서의 효과 등의 장점이 있으나, 값비싼 장비 가격 과 치료 비용, 사전에 계산되어진 셋팅으로 인한 치료 중 변수발생에 대한 조절의 어려움이 있다.

현재까지 만성 요통환자를 위한 다양한 치료 효과에 관한 연구는 지속적으로 이루어져 왔고, 관절가동기법과 굴곡-신연기법을 병행 한 치료와 척추감압치료에 대한 각각의 치료법들이 다른 보존적인 치료방법들보다 효과적이라는 점이 인정되고 있지만, 두 치료법에 관 해 비교한 연구는 부족한 실정이다. 따라서 본 연구의 목적은 만성적 인 요통을 호소하는 환자들에 대해 관절가동기법과 굴곡-신연기법 을 통한 치료 방법이 통증과 기능에 어떠한 영향을 미치는 지에 대해 척추감압치료와 비교 분석하여 만성 요통에 대한 치료방법의 방향 성을 제시하여 효과적인 처치 방법을 제공하고자 한다.

\section{연구방법}

\section{1. 연구대상}

본 연구는 2016년 10월 31일부터 12월 10일까지 6주동안 대구소재 S
정형외과에 입원한 환자와 외래로 내원한 환자 중 임신이나 생리, 비 뇨기계 등의 감염으로 인한 통증을 제외한 근골격계의 문제로 인한 만성 요통으로 진단 받고 통증이 지속된 지 3개월 이상 된 30세에서 60세 사이의 성인 30 명을 대상으로 척추감압치료를 실시한 대조군 15 명(남자 4 명, 여자 11 명)과 도수치료인 관절가동기법과 굴곡-신연기 법을 실시한 실험군 15 명(남자 4 명, 여자 11 명)을 무작위로 두 그룹으 로 나누어 실시하였다. 본 연구의 의도와 실험 전 과정에 대한 내용을 충분히 설명한 후 자발적 동의를 얻어 실시하였으며 요통을 제외한 근골격계 질환이나 특이한 병력이 없는 자로 선정하였다.

\section{2. 실험방법}

1) 측정도구

(1) 통증

통증정도를 알아보기 위해 시각적 상사 척도(visual analogue scale, VAS)방법을 이용하였다. $100 \mathrm{~mm}$ 의 수평자에 왼쪽 끝은 통증이 없는 아주 편안한 상태, 오른쪽 끝은 대상자가 생각하기에 극심한 통증으 로 참을 수 없는 통증으로 정의되도록 하여 그 선상에 검사자의 질문 을 듣고 통증의 정도를 수평자위에 표시하도록 하였다. VAS는 다양 한 증상, 특히 통증의 강도와 주기를 측정하기 위해 역학 및 임상 연 구에 흔히 사용되고, 다른 심리현상이나 증상의 정도, 기능이나삶의 질 등을 측정하는 데에도 광범위하게 이용되고 있다. ${ }^{18}$ 또한 다양한 환경에서 쉽게 사용할 수 있으며 적용에 필요한 연습시간이 적게 걸 릴 뿐만 아니라, 측정된 자료의 변수는 통계처리가 가능한 특징을 가 지고 있다. ${ }^{19}$

(2) 기능장애

요통으로 인한 기능 장애 정도를 평가하기 위해 오스웨스트리 요통 장애 지수(Oswestry disability index, ODI)를 이용하였다. ODI는 장애 변화에 가장 민감한 자가인지 도구이며, 척추질환의 관리에 이용되 는 주요한 조건별 결과 측정법의 하나이다. ${ }^{20} 10$ 개의 문항(통증 정도, 자기 관리, 들기, 걷기, 앉아 있기, 서 있기, 잠자기, 성생활, 사회생활, 여 행)은 기능적 수행 능력에 따라 0 점에서 5 점까지 점수로 측정하며, 점 수가 높을수록 장애가 심한 것을 뜻한다. 본 연구에서는 배우자가 없 는 대상자를 고려하여 성생활 항목을 제외한 9 개 항목을 적용하였 다. 9 개 항목은 각각 6 개의 문항으로 되어 있고 각 항목을 측정한 점 수를 합하여 항목의 총점인 45 점으로 나눈 값을 $\%$ 로 하여 $0-20 \%$ 는 경증장애(minimal disability), 21-40\%는 중등도 장애(moderate disability), 40-60\%는 중증장애(severe disability), $60 \%$ 이상은 생활전반의 장 애(severely disabled life)로 구분한다. 점수의 계산은 답한 문항의 총 점 수를 백분율로 환산하여 표시하였다. ${ }^{21,22}$ 


\section{2) 연구방법}

(1) 관절가동기법

관절가동기법은 적용하는 분절에서 대상자를 옆으로 누운 자세에 서 엉덩관절과 무릎관절을 굴곡시킨 후 실시하였으며, 관절가동기법 은 각각 10 회씩 적용하여 총 20 분을 다음과 같이 실시하였다. ${ }^{23}$

(1) 허리뼈분절의 굽힘 가동기법(lumbar segmental flexion mobilization) 연구자의 한손은 대상자의 허리뼈 후방에 놓고 동시에 손가락을 치 료하고자 하는 분절의 머리쪽에 위치한 추골의 가로돌기나 가시돌기 를 고정시키고, 다른 쪽 손은 대상자의 엉치뼈에 놓고 손가락을 치료 하고자 하는 분절의 꼬리쪽에 위치한 추골의 가로돌기나 가시돌기에 놓고 골반을 꼬리쪽-배쪽(caudal-ventral direction)으로 움직여 분절에 서 굴곡시킨다.

(2) 허리뼈분절의 폄 가동기법(lumbar segmental extension mobilization) 연구자의 한손은 대상자의 허리뼈에 놓고 동시에 시지를 치료하고자 하는 분절의 머리쪽에 위치한 추골의 가시돌기 후방에 위치시켜 고 정시키고, 다른 쪽 손은 대상자의 양쪽 하퇴와 무릎관절의 후방을 감 싸 쥐고 대상자의 양쪽 다리와 골반을 후방으로 움직이게 하여 허리 뼈분절을 신전시킨다.

(3) 허리뼈분절의 견인 가동기법(lumbar segmental traction mobilization) 연구자의 한쪽 아래팔과 손을 대상자의 허리뼈에 밀착시키고 시지와 중지는 치료하고자 하는 분절의 머리쪽에 위치한 추골을 고정시킨 후, 다른 쪽 팔과 손을 대상자의 엉치뼈에 밀착시키고 시지와 중지로 치료하고자 하는 분절의 꼬리쪽에 위치한 추골에 놓고 가슴부위를 대상자의 넓적다리와 골반 앞부분에 밀착시켜 치료하고자 하는 분 절에서 견인이 일어나도록 팔과 몸통을 하나의 단위처럼 사용하여 움직인다.

\section{(2) 굴곡신연방법}

굴곡-신연기법은 Zenith-Cox flexion table(Zenith-100, USA)을 이용하 였다. 대상자는 엎드려 누운자세에서 연구자의 한 손은 치료하고자 하는 허리뼈 가시돌기에 모지구(thenar)로 접촉해 고정하고 다른 손 은 말미부분의 손잡이를 잡고 테이블의 꼬리측 골반 분절(caudal pelvic section)을 아래로 내려 4-5초씩 5 회의 굴곡-신연 동작을 가해 총 20 초간의 신연이 가해지도록 하였으며, 꼬리측 분절을 아래쪽으로 움직일 때는 $5 \mathrm{~cm}$ 정도까지만 내려 전체 적용 횟수는 20 초 적용, 5 회 반복을 $1 \mathrm{set}$ 로 하여 $3 \mathrm{set}$ 까지 실시하였다. 굴곡-신연기법을 적용한 후 한 손으로 대상자의 머리를 연구자의 손으로 고정시키고 테이블 의 하단를 아래로 내려 굴곡-신연 동작을 적용하는 큰구멍 펌프(fo- ramen magnum pump)기법을 10 회 반복하였다. ${ }^{24}$

\section{(3) 척추감압치료}

척추감압치료기(MID 4 M Serise, WIZ medical, KOR)를 이용하여 대 상자는 치료기 위에 바로 누운 자세로 눕고 공기압 견착방식(air grip extension)을 이용하여 골반, 가슴부위, 머리에 벨트로 고정하고 요추 의 전만을 유지하기 위하여 공기압 펌프 엉치뼈 고정 보드(sacrum extension) 장치를 적용하였다. 견인력은 처음 강도 4-5에서 시작하여 점 차 강도를 한 단계씩 일정비율로 증가시켰으며 견인력 증가에 따른 통증 발생 시 견인력을 낮추거나 유지시켰다. 견인치료 시간은 20 분 이며 유지시간(hold time) 10 초와 휴지시간(rest time) 5 초로 설정하여 표준감압방식과 분할감압방식을 동시에 적용하였다.

본 연구에서 실험군은 관절가동기법과 굴곡-신연기법을 적용하였 고, 대조군은 척추감압치료를 적용하였다. 실험군과 대조군의 모든 대상자에게 먼저 온열치료 20 분, 간섭파치료 $100 \mathrm{bps} 15$ 분, 초음파치 료 5 분을 통증 부위에 동일하게 적용하였다. 각 대상자들은 주 3 회, 총 6주 동안 실시하였다.

\section{3. 자료분석}

본 연구의 목적을 위하여 수집된 자료는 SPSS /PC Ver.13.0을 이용하 여 분석하였으며, Shapiro-Wilk 검정 방법을 이용하여 정규 분포임을 확인하였다. 대상자들의 일반적인 특성은 기술통계방법을 사용하였 고, 각 군의 실험 전과 후의 유의성 검정은 대응표본 t-검증(paired ttest)을 실시하였으며, 각 군간 실험 전과 후의 변화량 차이의 유의성 검정은 독립표본 t-검증(independent t-test)을 실시하였다. 통계학적 유 의 수준은 0.05 로 하였다.

\section{결 과}

\section{1. 연구 대상자의 일반적 특성}

실험군의 평균 연령은 $48.6 \pm 9.4$ 세, 평균 신장은 $160.2 \pm 6.0 \mathrm{~cm}$, 평균 체 중은 $62.3 \pm 12.0 \mathrm{~kg}$ 이었다. 대조군의 평균 연령은 $46.1 \pm 8.5$ 세, 평균 신 장은 $162.7 \pm 9.1 \mathrm{~cm}$ 평균 체중은 $59.3 \pm 11.9 \mathrm{~kg}$ 이었다. 연구 대상자의 일 반적 특성에 대한 두 집단 간의 유의한 차이는 없었다( $\mathrm{p}>0.05$ )(Table 1$).$

\section{2. 시각적 상사 척도 비교}

실험 전, 후 VAS의 변화에서, 실험군은 $6.40 \pm 0.34$ 에서 $4.53 \pm 0.39$ 로 감 소하여 유의한 차이가 있었고 $(\mathrm{p}<0.05)$, 대조군도 $6.27 \pm 0.42$ 에서 4.27 \pm 0.36 로 감소하여 유의한 차이가 있었다 $(\mathrm{p}<0.05)$. 각 군의 실험 전, 후의 집단 간의 비교에서는 유의한 차이가 없었다( $>>0.05$ )(Table 2). 
Table 1. General characteristics of subjects

\begin{tabular}{lccc}
\hline Group & $E G(n=15)$ & $C G(n=15)$ & $p$ \\
\hline Age (year) & $48.6 \pm 9.4$ & $46.1 \pm 8.5$ & 0.440 \\
Height $(\mathrm{cm})$ & $160.2 \pm 6.0$ & $162.7 \pm 9.1$ & 0.525 \\
Weight $(\mathrm{kg})$ & $62.3 \pm 12.0$ & $59.3 \pm 11.9$ & 0.453 \\
\hline
\end{tabular}

Mean \pm SD: mean \pm standard deviation, CG: control group, EG: experimental group.

Table 2. Comparison of VAS in inner-groups and between groups

\begin{tabular}{lcccc}
\hline Group & Pre & Post & $\mathrm{t}$ & $\mathrm{p}$ \\
\hline EG & $6.40 \pm 0.34$ & $4.53 \pm 0.39$ & 6.424 & $0.000^{*}$ \\
$\mathrm{CG}$ & $6.27 \pm 0.42$ & $4.27 \pm 0.36$ & 4.830 & $0.000^{*}$ \\
$\mathrm{t}$ & -0.248 & -0.505 & & \\
$\mathrm{p}$ & 0.806 & 0.618 & & \\
\hline
\end{tabular}

CG: control group, EG: experimental group, VAS: visual analogue scale.

Table 3. Comparison of ODI in inner-groups and between groups

\begin{tabular}{lcccc}
\hline Group & Pre & Post & $t$ & $p$ \\
\hline EG & $33.75 \pm 18.40$ & $21.94 \pm 13.48$ & 3.676 & $0.002^{*}$ \\
CG & $29.72 \pm 12.25$ & $18.89 \pm 9.80$ & 4.581 & $0.000^{*}$ \\
$t$ & 0.729 & 0.733 & & \\
$p$ & 0.473 & 0.470 & & \\
\hline
\end{tabular}

CG: control group, EG: experimental group, ODI: Oswestry disability index.

\section{3. 오스웨스트리 요통 장애 지수 비교}

실험 전, 후 $\mathrm{ODI}$ 의 변화에서, 실험군은 $33.75 \pm 18.40$ 에서 $21.94 \pm 13.48$ 로 감소하여 유의한 차이가 있었고 $(\mathrm{p}<0.05)$, 대조군도 $29.72 \pm 12.25$ 에서 $18.89 \pm 9.80$ 로 감소하여 유의한 차이가 있었다 $(\mathrm{p}<0.05)$. 각 군의 실험 전, 후의 집단 간의 비교에서는 유의한 차이가 없었다 $(\mathrm{p}>0.05)$ (Table 3).

\section{고 찰}

본 연구는 3 개월이상 지속된 만성요통환자 30 명을 대상으로 효과적 인 치료 방법과 치료 방향을 제시하기 위하여 관절가동기법과 굴곡신연기법의 효과를 척추감압치료와 비교, 분석하였다.

본 연구에서는 통증 정도를 측정하기 위해 VAS 검사를 실시하였 다. VAS의 변화는 도수치료 방법 중 하나인 관절가동기법과 굴곡-신 연기법을 실시한 실험군과 척추감압치료를 실시한 대조군 모두에서 실험 전에 비해 실험 후 유의한 통증 감소를 보였다. Ferreira 등 25 의 연 구에서도 만성요통환자를 대상으로 척추도수치료를 시행한 결과, VAS가 치료 전 6.2 에서 치료 후 4.1로 통계학적으로 유의한 차이가 있 다고 보고하였다. 또한 Giles 등 26 은 만성 요통환자를 대상으로 척추 도수치료를 실시하여 VAS가 통계학적으로 유의하게 감소하여 본 연 구와 유사한 결과를 보였다. 관절가동기법과 굴곡-신연기법으로 인 한 통증감소의 원인은 척수와 뇌간 단계에서 통증 자극의 전달을 억
제하는 기계적 수용기를 자극하고 관절을 가동시키는 척추 도수치 료가 관절의 움직임을 통한 척추의 통증민감성 조직인 인대와 관절 낭의 자극전달을 감소시켜 통증 감소가 나타났고, 고유수용성 감각 이 유해성 자극 인식에 선행하여 정상신경발화를 자극함으로써 통 증을 감소시키는 것으로 보고하였다. ${ }^{27,28} \operatorname{Ramos}$ 와 $\operatorname{Martin}^{29}$ 은 척추감 압치료 후 통증감소에 유의한 효과가 있다고 보고하였다. 또한 요추 추간판 탈출증 환자에게 척추감압치료를 적용하여 탈출된 디스크 의 축소와 디스크의 재생에 긍정적인 영향, 통증과 유연성 및 근 활성 도에서 유의한 효과가 있다고 보고하였다. ${ }^{30}$ 본 연구에서도 척추감압 치료 후 VAS 검사를 통한 통증 감소를 보였으며 그 원인으로는 통증 의 원인이 되는 척추 디스크 부위를 조준하여 감압을 반복함으로써 추간판 내의 압력을 부분 무중력 상태로 만들고 이런 환경에서 탈출 되었던 디스크가 정상위치로 되돌아오기도 하고 수분, 혈액, 그리고 여러 영양소들의 원활한 소통을 도와 통증을 해결하며 자연치유력 증진을 도와준 것으로 사료된다.

본 연구에서 기능 장애를 측정하기 위해 ODI를 실시하였다. ODI 의 변화는 관절가동기법과 굴곡-신연기법을 실시한 실험군과 척추 감압치료를 실시한 대조군 모두에서 실험 전에 비해 실험 후에 유의 한 기능장애 감소를 보였다. Sutlive 등31은 요추와 골반에 도수치료를 한 그룹과 요추 척추후관절에 척추 도수치료를 실시한 그룹을 비교 하였을 때 두 그룹 모두 ODI 점수에서의 변화에 통계학적으로 유의 하게 감소하였으며, 요추신경병증을 지닌 L4-5, L5-S1 추간판 탈출증 환자에게 Cox 신연치료를 6주 실시한 후 통증과 ODI가 약 90\%개선 되었다고 보고하였다. ${ }^{32}$ Ghroubi 등 ${ }^{33}$ 은 64 명의 만성요통환자를 대상 으로 4주간 척추 도수치료를 실시한 결과 ODI에서 통계학적으로 유 의한 효과를 나타내었다고 보고하여 본 연구와 유사한 결과를 보였 다. 본 연구에서도 척추도수치료를 만성요통환자에게 6주간 실시한 결과 ODI가 통계학적으로 유의하게 감소한 결과를 보였으며 중등도 장애에서 경증 장애에 가까운 향상을 보였다. 이러한 결과는 제한된 관절운동이 원할해지면서 관절강 내 운동기능의 향상으로 인한 결 과로 사료된다. 또한, 굴곡-신연기법(flexion-distraction manipulation) 으로 인해 척추관 안에서 시상직경의 확장, 후부의 운동단위 개방, 추 간판내의 압력을 감소, 추간판 사이에 공간 확장, 전종인대와 후종인 대가 신전되어 추간판이 스스로 재배열됨으로써 고착되었던 후관절 열림과 요추자세의 재배열로 통증감소, 운동기능 향상, 자세교정을 통해 다양한 일상생활동작의 증진이 된다고 보고하였다. ${ }^{34,35}$ Gose 등 ${ }^{36}$ 은 감압치료가 통증을 감소시키고 가동성을 증가시키며 MRI영상 의 변화에서 유의한 효과가 있었다고 하였다. $\mathrm{Ma}$ 등 ${ }^{37}$ 도 요추 신경뿌 리병증 환자에게 척추감압치료를 적용하여 $\mathrm{ODI}$ 와 근력개선의 증진 을 보여 본 연구와 유사한 결과를 보였다. 특히 본 연구에서 ODI에서 는 중등도 장애에서 경증장애로 향상을 보였다. 이러한 결과는 척추 
감압치료가 추체의 분리를 통해 추간공의 직경을 증가시키고, 신경 조직에 대한 압력을 완화시킴으로써 방사통과 신경학적 결손을 줄 일 수 있었고, 척추사이원반의 스트레스 감소, 척추사이원반의 공간 확보로 신경자극을 완화시켜 움직임의 방해가 줄어든 것으로 예상 할 수 있다. ${ }^{38}$

각 군의 측정전과 측정후의 집단간 $\mathrm{VAS}$ 와 $\mathrm{ODI}$ 는 측정전과 측정 후 모두 통계학적으로 유의한 차이가 없었다. 이러한 결과는 관절가 동기법과 굴곡-신연기법을 적용한 실험군과 척추감압치료를 실시한 대조군 모두에서 추간판 내의 압력을 감소시킬 뿐만 아니라 추간판 의 간격을 넓혀주고 후부의 운동단위가 활성화가 된 것으로 사료된 다. 또한 제한된 관절운동이 원활해지고 관절낭 내 운동기능의 향상 으로 고착된 후관절이 열림으로 인해 요추 자체의 재배열 향상, 압박 된 신경과 긴장된 근육의 감소로 요추부위의 통증과 기능에서 동반 향상 된 것으로 볼 수 있다.

본 연구의 결과로 관절가동기법과 굴곡-신연기법을 이용한 도수 치료와 척추감압치료는 임상에서 만성요통 환자에게 적용 시 통증 감소와 기능 증진에 있어서 유사한 효과가 있을 것으로 사료된다. 그 러나, 비교적 높은 장비 가격과 치료 비용의 발생, 치료 중에 유발할 수 있는 다양한 변수로 인한 재셋팅으로 인한 시간 지연 및 불편함을 주는 척추감압치료의 단점을 대신할 수 있는 도수치료가 임상적으 로 볼 때 효율성이 높을 것이다.

본 연구의 제한점은 6주 동안의 비교적 짧은 기간과 대상자 수의 부족으로 일반화하여 해석하기에는 부족함이 있고, 대상자들의 완전 한 일상생활 통제에 한계가 있었던 점, 각 치료방법에 대한 장단점을 확인하지 못한 점을 볼 수 있다. 향후 연구에서는 다양한 요통의 원인 에 따른 적합한 치료방법에 관한 장기적인 연구가 필요할 것이다.

\section{참고문헌}

1. Kim SB. Effect of manual adjustment and gym-ball exercise on sEMG, Cobb's angle, VAS, flexibility, and strength in elderly women with low back pain symptom. Kyung-hee University. Dissertation of Doctorate Degree. 2012.

2. Kang SS, Goo BO. The effects of yoga low back pain exercise and lumbar extensor muscle endurance exercise on chronic low back pain patients. J Kor Phys Ther. 2012;24(2):107-12.

3. Fordyce WE, Brockway JA, Bergman JA et al. Acute back pain: a controlgroup comparison of behavioral vs traditional management methods. J Behav Med. 1986;9(2):127-40.

4. Lee WJ, Park SI. The effect of cigarette smoking on physical fitness and depression of patients with chronic low back pain. J Kor Phys Ther. 2015;27(4):275-80.

5. Song GB, Park EC. Effects of neck and trunk stabilization exercise on balance in older adults. J Kor Phys Ther. 2016;28(4):221-6.

6. Seo JK, Kim SY. The Relationship between hip abductor muscle strength and lumbar instability in patients with chronic low back pain. J Kor Phys Ther. 2011;23(4):15-22.

7. Andersson GB. Epidemiological features of chronic low-back pain. Lancet. 1999;354(9178):581-5.

8. Yuk GC, Park SH, Kim CS. Kinematics analysis of lumbar spine during breathing in lying position purpose. J Kor Phys Ther. 2011;23(5):15-21.

9. Kim K, Kim EK, Lee DK. Effects of PNF patterns exercise on pain, functional disability and fear avoidance belief in chronic low back pain patients. J Kor Phys Ther. 2014;6(2):110-6.

10. Kong YS, Hwang YT. Comparison of the activity and proprioception of trunk muscles according to different types of bridge exercises in subjects with and without chronic low back pain. J Kor Phys Ther. 2015;27(6): 400-6.

11. Bae SS, Kim SY, Kim TY et al. Orthopedic physical therapy. 3th ed. Seoul, Dae-Hag, 2009.

12. Kim HB, Kim SY, Kim YM. The comparison about a evaluation and treatment concept of the manual therapy techniques. J Kor Aca Ortho Manu Ther. 2005;11(1):49-64.

13. Kisner C, Colb LA. Therapeutic exercise: foundation and techniques. 2nd ed. Philadelphia, FA Davis, 1990.

14. Godges JJ, Mattson-Bell, Shah D et al. The immediate effects of soft tissue mobilization with proprioceptive neuromuscular facilitation on glenohumeral external rotation and overhead reach. J Orthop Sports Phys Ther. 2003;33(12):713-8.

15. Onel D, Tuzlaci M, Sari H et al. Computed tomographic investigation of the effect of traction on lumbar disc herniations. Spine. 1989;14(1):8290.

16. Gudavalli MR, Cambron JA, McGregor M et al. A randomized clinical trial and subgroup analysis to compare flexion-distraction with active exercise for chronic low back pain. Eur Spine J. 2006;15(7):1070-82.

17. Gionis, Thomas A, Groteke E. Spinal decompression. Orthopedic technology review. 2003;5:36-9.

18. Paul-Dauphin A, Guillemin F, Virion JM et al. Bias and precision in visual analogue scales: a randomized controlled trial. Am J Epidemiol. 1999;150(10):1117-27.

19. Philip BK. Parametric statistics for evaluation of the visual analog scale. Anesth Analg. 1990;71(6):710.

20. Fairbank JCT, Pynsent PB. The Oswestry disability index. Spine. 2000;25(22):2940-52.

21. Lee HJ, Song JM. Analysis of the characteristics of patients with chronic low back pain using the ICF concept. J Kor Phys Ther. 2013;25(5):282-7.

22. Lee HJ, Song JM. Mapping items of functioning questionnaires into the international classification of functioning, disability and health: low back pain. J Kor Phys Ther. 2016;28(5):321-7.

23. Kaltenborn FM, Evjenth O, Kaltenborn TB et al. The spine: basic evaluation and mobilization techniques. 3rd ed. Oslo, Olaf Norlis Bokhandel, 1993.

24. Kwon WA, Ryu Y-Sa, Ma SY. The effects of Cox distraction manipulation on functional assessment measures and disc herniation index in patients with L4-5 herniated disc. J Kor Data and Info Sci Soc. 2012;23(4): 727-38.

25. Ferreira ML, Ferreira PH, Latimer J et al. Comparison of general exercise, motor control exercise and spinal manipulative therapy for chronic low back pain: a randomized trial. Pain. 2007;131(1-2):31-7. 
26. Giles LG, Muller R. Chronic spinal pain: a randomized clinical trial comparing medication, acupuncture, and spinal manipulation. Spine. 2003;28(14):1490-502.

27. Gillette RG, Kramis RC, Roberts WJ. Characterization of spinal somatosensory neurons having receptive fields in lumbar tissues of cats. Pain. 1993;54(1):85-98.

28. Kim SY. The effect of mobilization for spinal facet joint on pin and ran of motion in patients with chronic low back pain. Catholic University. Dissertation of Master's Degree. 2011.

29. Ramos G, Martin W. Effects of vertebral axial decompression on intradiscal pressure. J Neurosurg. 1994;81(3)350-3.

30. Kwon WA, Lee SH, Lee JH. Effects of decompression therapy for 6 cases with lumbar herniated disc. J aca indu tech, 2012;13(5):2133-41.

31. Sutlive TG, Mabry LM, Easterling EJ et al. Comparison of short-term response to two spinal manipulation techniques for patients with low back pain in a military beneficiary population. Military Med. 2009;174(7): 750-6.

32. Kruse RA, Gudavalli S, Cambron J. Chiropractic treatment of a pregnant patient with lumbar radiculopathy. J Chiro Med. 2007;6(4):153-8.

33. Ghroubi, S, Elleuch H, Baklouti S et al. Chronic low back pain and vertebral manipulation. Ann Readapt Med Phys. 2007;50(7):570-6.

34. Adams M, Hutton W. Prolapsed intervertebral disc: a hyperflexion injury. Spine. 1982;7(3):184-91.

35. Kim MC, Kim. HS. Effect of fatigue on EMG activity and dynamic balance of subjects with functional lumbar instability. J Kor Phys Ther. 2015;27(4):207-13.

36. Gose EE, Naguszewski WK, Naguszewski RK. Vertebral axial decompression therapy for pain associated with herniated or degenerated discs or facet syndrome: an outcome study. J Neuro Res. 1998;20(3):186-276.

37. Ma SR, Kwon WA, Lee JH et al. The Effects of spinal decompression combined with therapeutic modalities for patients with lumbar radiculopathy. J aca-ind tech. 2013;14(1):336-43.

38. Park SH, Kim CS, Lee DG et al. The short term effects of the decompression $\left(\mathrm{KNX} \$ 7000^{\wedge} \$\right.$ ) and traction device on pain in patients with chronic low back pain with or without radicular pain. J Kor Phys Ther. 2011;23(5):29-34. 